\title{
Africa and the West: Between Tradition and Modernity in Shimmer Chinodya's Dew in the Morning (1982) and Ngugi WA Thiongo's weep Not, Child (1964)
}

Babacar DIAKHATÉ

Laboratoire d'Études africaines et postcoloniales Université Cheikh Anta Diop Dakar, Sénégal diakhatebabacar83@hotmail.f

\begin{abstract}
European colonizers have impoverished Africans for spoiling their natural resources. African Anglophone writers such as Shimmer Chinodya and Ngugi WA Thiongo respectively in Dew in the Morning and Weep Not, Child devote most of their writings to land issues and cultural alienation. The aim of this article is to display the strategies of the White man to achieve his objective, and the contribution of his black collaborators to take Africans' lands. It also reveals the importance of African traditional practices in the resistance against colonialism. Finally, it shows the perpetual quest of western education by Africans to "beat the white in his own game".
\end{abstract}

Keywords

Colonization, Land, Education, Tradition, Alienation

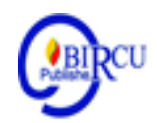

\section{Introduction}

The confiscation of Africans' lands by the whites leads some writers to denounce colonialism. Shimmer Chinodya and Ngugi WA Thiongo respectively from Zimbabwe and Kenya fictionalize the relationship between the colonizers and the colonized.

In Dew in the Morning, the colonizer manipulates and divides the black community into two groups: the Derukas who move from the South, inhabited by the Whites, to settle in the North occupied by the Local people. Similarly, the guerilla Mau Mau war is also an incentive factor that pushes Ngugi WA Thiongo to release Weep Not, Child. In the novel, Njoroge does his utmost to resist the white man through education.

The present researcher believes that it may be seen as a kind of Orientalism in TGST. Loomba, in her book Colonialism/Postcolonialism (1998), believes that anti-colonial or nationalist movements have tried to show the image of the Nation-as-Mother to make their own ancestors "and also to control the activity of women within the imagined community. [...] these movements encourage women to create 'sons who may live and die for the nation" (180). The nation is shaped as a home, and its leaders are like paternal roles and fellowcitizens are brothers and sisters. For example, "the King was a Father to his people" (ibid 81). The family and the State completed each other.In colonialism, the family becomes the symbol of anti-colonial movement because it indicates inner space (182). When appropriated families of colonized subjects in colonial situation and intrusions were imagined, "the family will be symbol of resistance". (Birgani, 2019)

The aim of this article is first to depict the role of the collaborators of the whites in their colonial agenda. The second part displays the perpetuation of African traditional beliefs such as, rain-making ceremonies, witchcrafts and Witchfinding, etc. The final section focuses on the modernization process of the population through education. It demonstrates whether education has helped Njoroge achieve his aim.

\section{Theoretical Framework}

\subsection{Black Skin, White Mask" or Whites' Collaborators}

In some South African countries, land issues are the sources of many social instabilities. After the departure of the whites from African countries, African leaders perpetuate Western colonial agenda. They gain advantage of Western education and become the collaborators of the whites in order to facilitate their domination. Mukoma WA Ngugi calls these collaborators "the traitors" in Black Star Nairobi and "Black Skin White Masks" to quote Frantz Fanon. 
In Dew in the Morning, Shimmer Chinodya castigates the way in which Jairos, the headmaster of the village, takes the lands from their owners to give them to the Derukas. The latter represent the white man and the incarnation of modernity. They subjugate and manipulate the headman of the village in order to get the best lands. The government displaces the blacks from the South to the North because of overpopulations and drought. Once they arrive in the North they are called the Derukas and the autochthone populations are the locals.

The long cohabitation of the Derukas with the whites influences them socially and culturally. They have frequented western education to the detriment of the locals who are considered to be ignorant and uncivilized people. They contribute to the education of the locals and give crates of bottled beer, bottles of wine and trivial stuff in exchange of better lands. Jairos attributes Masiziva's lands to the Pendis family because of corruption. Jairos asserts:

Very soon you will be having the Pendis as your neighbors. Pendi will be coming to build his huts in

June...Last time he came he brought me 2 crates of bottled beer and 2 bottles of gin. Now that's a man

I wouldn't mind taking into my village. I want this village to be full of people like Pendi so that we can have beer parties every night (Chinodya, 1982:14).

In Weep Not, Child, Ngugi also castigates the collaborators of the whites in his novel. If the white man succeeds in ruling the population and achieves his aim it is thanks to his collaboration with Jacobo. He is a black man who symbolizes the African leaders. He betrays his populations in favor of the white man. $\mathrm{Mr}$ Howlands manipulates black people through his strategy of division. Ngugi puts: Mr Howlands despised jacobo because he was savage. But he would use him. The very ability to set these people fighting among themselves instead of fighting with the white man gave him an amused satisfaction (Ngugi, 1964:77).

Like the Derukas who symbolize the bourgeois in Dew in the Morning, in Weep Not

\section{Discussion}

\subsection{Traditional Practices}

Before the advent of science and technology, Africans could find solutions to natural catastrophes such as drought, epidemics, famine, etc. The populations solve their problems thanks to some traditional practices inherited from their ancestors like rain-making ceremonies and Witchfinding.

\section{A-Rain-Making Ceremonies}

The over use of land can bring about its infertility. Agriculture is one of the main activities in the South. In Dew in the Morning, Shimmer Chinodya shows the solution resorted to by Jairos and his villagers to bring rain. There was a drought and the presence of Madoras which were as destructive as locusts. They even ate the foliage of the branches in the village and farms. The Madoras put the country in an alarming situation.

As a solution, Jairos recommends rain-making ceremonies in the village. All the populations have gathered in Jairos's compound. The person in charge of this traditional practice is a light-skinned woman in her thirties. The silence that prevails in the village and the fact that Jairos kowtows in front of the woman shows both: the importance of the event and the respect for the rain-maker. Ngugi puts Jairos stood above the rain-maker, lowing his head as he bent down to say something to her. Simon shouted from the crowd angrily advising Jairos to revise his manners and crouch as he talked to her. There was silence (Chinodya, 1982:25). In the ceremony, the songs are combined with drums beating. Women start dancing. The rain-maker advises: There were two strange birds to be caught and destroyed, and a dead woman's hut to be burnt. The two birds lodged within the trunk of a tree on the borders of our homestead (Chinodya, 1982: 27).

After the rain-making ceremony, the rain falls heavily all around the village. This practice shows that African tradition is very rich and plays a useful social function. The rain fall symbolizes the end of the hard time of the rural populations and "sun rise". The locust and Madora reveal the disaster caused by the colonizers. The presence of the white man is assimilated to "darkness" in the Africans. It is also the transition from the whites' departure to the re-appropriation of African lands. 


\subsection{Witchcraft and Witchfinding}

Even though the West is accused of being responsible for most evils that happen in Africa, Africans themselves have an important part of responsibilities. After the departure of white missionaries from Jairos' Village, the local people are constantly in conflict. In Dew in the Morning, Shimmer Chinodya reveals the dark practices that Africans should get rid of. For him, an African can kill another African for Jealousy. He presents Jeni, a hard-working woman who is bewitched and possessed by Mai Mapanga's evil spirit. Mapanga is jealous of Jeni. He even menaces to kill her: Let me kill her to see who will work for her parents. She thinks she is a tractor and yet she is only a girl (Chinodya, 1982: 165).

As Jairos did by creating rain-making ceremonies, Simon, the new headmaster of the village calls for a witchfinder. The village is overwhelmed with withcrafts and he decides to clean it. Chikanga, the withcfinder, asks a cow from every member of the village as a compensation. Chikanga warns:

This is a mirror through which I will observe people's characters. This is my water. Each one of you will touch the bottle. Whoever touches my bottle and turns this water red is a deadly killer, an eater of human flesh. Whoever turns the water brown or grey is a mild offender, but a dangerous person all the same. Whoever touches the bottle and leaves my water as it is, is an innocent as a baby (Chinodya, 1982: 205).

Masiziva is possessed by his dead father's spirit. Makepsi kills Jeni and Jairos. This Witchfinding refers to the doom's day. Mapanga is considered as a "God" and his girls are his "angels". In this practice the good and innocent persons like Jeni and Masiziva are rewarded and Makepsi is severely punished.

After the Witchfinding, the rain falls and the harvest becomes more abundant. The new fresh air blowing throughout the village symbolizes happiness and the hope for a better life in the village. Chinodya asserts: No one, nothing came and stayed. Each had promised a fresh start but the many callings of life had torn them away. All that remained were memories and (Chinodya, 1982: 215).

\subsection{Illiteracy and Unawareness}

The collaborators of the white man and the lack of western education make the mission possible. The local populations are unconscious of the importance of western education. They prefer the fields to schools. The discussion between Masiziva and Jairos about Lulu's birthday is illustrative. Jairos does not know his daughter's birthday. He affirms that Oh, yes I remember she was born when the road from town reached this village (Chinodya, 1982: 5). Jairos and all the villagers are ignorant people. According to Simon, the finality of education is only reading and writing letters. He proposes that Masiziva's sons should be taken out of school. Simon asserts one of them can even teach in our village school. The others can work as office clerks in the district commissioner's office (Chinodya, 1982: 88). For Simon, going to university is a waste of time.

The lack of education can create a sentiment of "inferiority" and "complexity" among people. This is evoked between Lulu and Godi's talk: She puts you wouldn't marry me. A girl who works in a shop? You, with your education (Chinodya, 1982: 169). Lulu keeps saying: Do you think your mother would be happy to have me in your home? If I had another father perhaps...or if I was educated...your mother likes me but do you really think she would accept me? Don't answer (Chinodya, 1982:170).

In the Bride Price, Buchi Emecheta denounces the lack of education of some African women. She advocates that education is the only solution to change women's predicaments in a patriarchal society. She vouches that:

School, they said, is no use to a free man. School is a place to send your slaves. That was another tradition. In the old days, when the white men first started their Christian schools, the local free men had no use for them...Later events showed, however, that it was these educated slaves who got the top of jobs. The sons and grandsons of these "slaves" families were now so rich and powerful that they seemed to command the respect of everywhere (Emecheta, 1989: 28).

Differently from Njoroge who chooses education to free his people from the white possession, Boro his brother underestimates education. He does not see it as a solution to their problem. Boro thinks that the best way to liberate his community is through violence. Since their parents are killed in their eyes, education is not the solution. Ngugi puts: the letter said that the head of the headmaster plus the heads of forty children would be cut off if the school didn't instantly close down (Wa Thiongo, 1964: 83). 


\subsection{Western Education}

Africans are very ingrained in their tradition and culture. This deep rootedness should not prevent them from being open to the rest of the world. The process of modernization starts necessarily with the introduction of Western education into rural areas. In Dew in the Morning and Weep Not, Child, Shimmer Chinodya and Ngugi WA Thiongo demonstrate that western education permits to "beat the White in his own game".

Western education is the only weapon for Africans to take back what belongs to them from the whites. In Dew in the Morning and in Weep Not, Child, the authors display how their respective characters are eager to attend western schools. Njoroge is devoted to go to school and he asks his mother to let him get a good western education. Like Njoroge, Godi also urges his parents to give him a chance to go to school. Both parents of family invest in their children's education in order to take over from them in the house responsibilities. The whole community relies on Njoroge to take back the lands of their ancestors. He is aware of this social burden.

Similarly, Godi and his brothers show to what extent their father is obsessed with Western education. Godi admits: our education was his burning obsession (Chinodya, 1982:140). Even though the local people are very attached to their lands, Mr Womambo places the education of his children on top of everything. He confesses:

Your education gets top priority, boys and that's why I think the fence must wait; That is why we can't buy cattle yet, and why we can't build ourselves a nice brick and zinc house.

Wire, cattle, and houses can wait but your education can't (Chinodya, 1982:78).

In Beyond the Horizon, Amma Darko reveals the importance of western education. Darko presents Akobi, the first young boy in Naka to have his certificate. He is the pride of his father and his community. Western education allows Akobi to read and write, which facilitates his migration to Germany. In Ambiguous Adventure, Cheikh Amidou Kane admits that education is part and parcel of people's social mobility and defense strategy. The Royal Lady defends that the only solution to make the white man and his agenda fail is a good western education.

Royal Lady puts:

Foreign school is the new form of war which those who have come here are waging, and must send our elite there, expecting that all the country will follow them(...) If there is a risk, they are best prepared to cope successfully with it, because they are most firmly attached to what they are (Kane, 1961).

\subsection{Hopes}

When Shimmer Chinodya and Ngugi WA Thiongo urged their characters to attend western school, it was based on hope. Godi's and Njoroge's parents hope that their sons will wrench back the lands of their ancestors. From a passion, education shifts to a social function. Njoroge wants to be educated, gets his diplomas and has a good and lucrative employment to help his parents. Njoroge prays: Lord! Let me get learning. I want to help my father and mother and Kamau and all my other brothers (Wa Thiongo, 1964:49).

Njoroge encounters many difficulties to make his dream comes true. All the members of the community contribute financially to help him continue his studies. Njoroge is the unique son in the village who can challenge Mr Howlands. The latter is famous for taking the lands of Njoroge's ancestors. Ngotho says: Education is everything (Wa Thiongo, 1964: 43). Moreover, in an interview, Ngugi puts: Education is tool and we should use this weapon to wrench back our independence from the colonial regime (Ngugi, Interview).

\subsection{Disappointment}

The hopes that Godi's and Njoroge's parents have for the education of their respective children turn into despair. In Weep Not Child, Ngugi shows how Njoroge, who has devoted all his activities to get a western education, fails. He does not achieve his aim. The hard time of his father and the menace that he receives here and there all contribute to his disillusionment. He has lost his faith, his education, his family and community. Njoroge's disappointment is the failure of a whole country. He admits: 
I have now lost all my education, my faith and family...I alone, am left. Hence the guilty of mine. I wanted to meet you and say that I am sorry. I have no hope left but for you, for now I know that tomorrow was an illusion... Mwihaki, dear I love you. Save me if you want. Without you I am lost (WA Thiongo, 1982:149-150).

Njoroge's resignation allows Mr Howlands to manipulate and ill-treat him. His family is ruined and his father is beaten to death.

Through the behavior of the white man, Chinodya displays the negative aspect of western education. In Dew in the Morning, he denounces the intention of the whites and the Derukas to change the way of life of the local people. The attempt of the Derukas to modernize the local people brings about disaster in the village. Indeed, the land is no longer fertile. Therefore, the agricultural production decreases. Famine prevails everywhere in the village and the cattle die little by little. Getting western education does not necessarily mean success. Kikuyu people own up that the education of their sons has not changed their lives. Ousmane Sembene castigates:

Ndeye Touti herself knew far more about Europe than she did about Africa; she had won the prize in geography several times in the years when she was going to school. But she had never read a book by an African author. She was quiet sure that they could teach her nothing (Sembene, 1962: 58).

\section{Conclusion}

The relationship between the West and Africa is based on strategies of domination and resistance. The first one divides the population in order to better rule. The second one resorts to African traditional beliefs and practices to resist the white man.

In Dew in the Morning, Chinodya uses Jairos, the headmaster, to illustrate the collaborator of the white man. He gives all the best lands of his village to the Derukas. Simon, the new headmaster after Jairos's death resorts to the tradition of his ancestors to heal the evils of the village such as drought, famine, locusts or Madora. In Weep Not, Child, Ngugi reveals Njoroge's failure after getting western education. He does not change neither the hard living conditions of his parents nor wrench back the lands of his community from $\mathrm{Mr}$ Howlands. The failure of Njoroge is the failure of the country. His mother realizes that the perpetual quest of education does not lead anywhere. She concludes: education is not life (WA Thiongo, 1964: 83). Njoroge, in turn, admits his failure: I have now lost all my education, my faith my family...I am alone, am left (WA Thiongo, 1964:149).

\section{References}

Achebe, Chinua (1958). Things Fall Apart, London: Heinemann.

Birgani, S. (2019). Feministic Analysis of Arundhati Roy's the God of Small Things in the Light of Post

Colonialism. Budapest International Research and Critics Institute-Journal (BIRCI-Journal). P. 172-181.

Chinodya, Shimmer, (2001). Dew in the Morning. London: Heinemann.

Darko, Amma, (1991). Beyond the Horizon. Der Verkauft. Heinemann.

Duerden, Deninis and PIERTERSE, Cosm. (1972). African Writers Talking, a Collection Interviews; Heinemann Educational Books Ltd, London.

Emecheta, Buchi, (1989). The Bride Price. Oxford: Oxford University Press.

Fanon, Frantz, (1952). Black Skin, White Masks. Edition du Seuil Grove Press.

Oyono, Ferdinand, (1956). The Old Man and The Medal, African Writers Series, Heinemann Educational books.

Kane, Cheikh Amidou, (1961). The Ambiguous Adventure. Heinemann.

Sembene, Ousmane, (1962). God's Bits of Woods. Double Day and Company.

Wa Thiongo, Ngugi, (1964). Weep Not, Child. Heinemann Educational Publishers.

Wa Ngugi, Mukoma, Black Star Nairobi, ((2013).Melville House. 